\title{
HOLISTIC AREA-WIDE APPROACH FOR SUCCESSFULLY MANAGING CITRUS GREENING (HUANGLONGBING) IN MEXICO
}

\author{
C. J. GARCÍA-ÁVILA, F. J. TRUJILLO-ARRIAGA, A. QUEZADA- \\ SALINAS, I. RUIZ-GALVÁN, D. BRAVO-PÉREZ, J. M. PINEDA- \\ RÍOS, J. G. FLORENCIO-ANASTASIO AND \\ P. L. ROBLES-GARCÍA
}

\begin{abstract}
General Directorate of Plant Health (DGSV) of Servicio Nacional de Sanidad, Inocuidad y Calidad Agroalimentaria (SENASICA), Guillermo Pérez Valenzuela 127, Coyoacán 04100, Mexico City, Mexico; clemente.garcia@senasica.gob.mx
\end{abstract}

\begin{abstract}
SUMMARY
The General Directorate of Plant Health (DGSV in Spanish) is recognized as the National Plant Protection Organization of the Federal Government of Mexico that acts under the Plant Health Federal Law. Some relevant plant protection programmes that Mexico is implementing include: The Huanglongbing (HLB) Asian Citrus Psyllid (ACP) Programme, Mediterranean Fruit Fly Programme, National Fruit Fly Campaign, Pink Hibiscus Mealybug Programme and a permanent Phytosanitary Epidemiological Surveillance Programme to prevent the introduction and spread of regulated non-native pests. HLB or citrus greening is caused by the bacterium, Candidatus Liberibacter spp., and considered the most devastating citrus disease in the world. Once infected, it causes the death of orange, mandarin, grapefruit and lemon trees within 3 to 8 years. HLB is transmitted by the ACP, (Diaphorina citri Kuwayama), an insect vector widely distributed in most citrus producing regions of the world, including the citrus areas of Mexico. Until 2004, the disease only existed in Asia and Africa. It was first reported to occur in the Americas in 2004 (São Paulo, Brazil) and 2005 (Florida USA). In 2009, it was detected for the first time in Yucatán, Mexico. During that year, the national Mexican citrus production was 6.82 million tons (SIAP 2017). The economic impact evaluation by Salcedo-Baca et al. (2010) indicated that without the intervention of the Federal Government, HLB would be responsible for a reduction of the Mexican citrus production by 2.7 million tons in five years (39.6\%). In spite of the spread of HLB, the citrus production in Mexico increased 11\% to 7.56 million tons in 2015 (SIAP 2017). Today Mexico has 573406 hectares (ha) of citrus compared to 545947 in 2009, an increase of 5\%. The first phytosanitary actions implemented on an area-wide basis were: (1) timely detection of HLB in agricultural and urban areas; (2) systematic elimination of infected trees in areas under surveillance; (3) control of the $D$. citri vector and (4) protection of propagative material in nurseries to avoid its infection. As a result of the successful HLB Programme implemented since 2008, adverse effects of the disease have largely been avoided. Management of HLB is organized through Regional Areas of Control (Areas Regionales de Control or ARCOs), which implement the following area-wide measures: epidemiological surveillance and monitoring of psyllids based on criteria associated to climate and host presence in urban
\end{abstract}

J. Hendrichs, R. Pereira and M. J. B. Vreysen (eds.), Area-Wide Integrated Pest Management: Development and Field Application, pp. 33-49. CRC Press, Boca Raton, Florida, USA.

(C) 2021 IAEA 
and cultivated areas, and chemical and biological controls. From 2010 to 2015, 31 million parasitoid wasps Tamarixia radiata (Waterston) were produced and released in commercial citrus and backyard host areas of Yucatán, Quintana Roo, Campeche, Tabasco, Chiapas, Oaxaca, Hidalgo and Guerrero. The ARCOs are public-private organizations jointly operated by federal and state governments together with citrus grower associations. In 2016, the Mexican government allocated almost USD 8.5 million to the HLB Programme. With these actions, Mexico has largely mitigated the adverse effects of the disease while at the same time slightly increased citrus production. In addition, research programmes have been established together with scientific institutions to generate vegetative material with tolerance or resistance to the disease. Although the government has successfully implemented area-wide strategies for regional control, it is necessary to develop new and improved technologies to eliminate the vector, following the example of the Mediterranean fruit fly Programme in Mexico.

Key Words: Asian citrus psyllid, Diaphorina citri, Candidatus Liberibacter, economic impact, Mexican states, citrus production, Tamarixia radiata

\section{INTRODUCTION}

Huanglongbing (HLB) or citrus greening is a disease native to China and is considered one of the most destructive citrus diseases in Asian countries where its occurrence was originally reported more than a century ago (Bové 2006). More recently this bacterium reached the American continent together with its insect vector, the Asian citrus psyllid (ACP) (Diaphorina citri Kuwayama), capable of infecting and causing considerable damage to plants in the family Rutaceae (Alemán et al. 2007; Bové 2012).

The current geographic distribution of HLB extends to 12 countries in Asia, several islands in the Indian Ocean, Iran, portions of Africa, the Arabian Peninsula, Argentina, Brazil, Paraguay, Central America (except Panama), Barbados, Belize, Cuba, Dominican Republic, Guadeloupe, Jamaica, Martinique, USA (including Puerto Rico and the U.S. Virgin Islands) and Mexico (da Graça and Korsten 2004; Halbert and Manjunath 2004; NAPPO 2005; Bové 2006; Manjunath et al. 2008; Collazo et al. 2009; Trujillo-Arriaga 2011). In 2009, HLB was detected in Mexico for the first time in the state of Yucatán, and now is known to occur in 24 Mexican states (SENASICA 2017a).

The HLB-causing bacterium mainly attacks sweet orange and mandarins (da Graça and Korsten 2004) although all citrus varieties have shown varying degrees of susceptibility to infection as well as other members of the Rutaceae family. Currently, there is no successful control method to cure this disease, and as a result, infected trees die in the course of a few years.

This disease is caused by Gram-negative bacteria of the genus Candidatus Liberibacter (Bové 2006). There are three species of HLB-associated bacteria: $\mathrm{Ca}$. L. asiaticus, $C a$. L. africanus and $C a$. L. americanus. All three have been described as the cause of HLB in different countries and climates world-wide (da Graça and Korsten 2004; Halbert and Manjunath 2004; Bové 2006; Wang et al. 2009), along with its insect vectors: ACP and the African psyllid, Trioza erytreae (Del Guercio). The first is the vector of $C a$. L. asiaticus and $C a$. L. americanus; while $T$. erytreae is the vector of $C a$. L. africanus. A fourth species, $C a$. L. caribbeanus, recently was identified from samples of ACP and Citrus sinensis (L.) Osbeck in Córdoba, Colombia. Efforts are underway to determine its pathogenicity and if it causes HLB symptoms (Keremane et al 2015). 
The main symptoms of HLB are asymmetrical blotchy mottle yellowing in leaves, chlorosis, fruit drop and foliar loss and tree death. In addition to reducing the size and quality of fruit, the disease causes malformations and bad taste of fruit (Schwarz et al. 1973; Bové 2006). Although infected trees can remain productive for 5 to 8 years, the fruit are of poor quality (Halbert and Manjunath 2004).

To date, no control strategy is available that allows the immediate elimination of the pathogen, so its management in commercial citrus production areas is limited to the control of psyllid vectors through the application of insecticides, elimination of symptomatic trees with the aim of reducing levels of inoculum, isolation of affected areas by quarantine enforcement, and certification of pathogen-free propagative material (da Graça and Korsten 2004; Bové 2006; Manjunath et al. 2008; Gottwald et al. 2012). Because infected orchards become economically non-viable after 7 to 10 years, efforts focus on elimination of infected trees that have caused losses worth billions of dollars on a global basis (Gottwald et al. 1991; Vojnov et al. 2010).

In Florida, introduction of HLB resulted in major changes to pest management practices and corresponding costs. According to Singerman and Burani-Arouca (2017), average annual pest control consisted of two sprays for processed juice fruit and six sprays for fresh market grapefruit mostly to control several minor diseases, mites and weevils. Following a series of hurricanes in 2004 and 2005, that resulted in the catastrophic spread of citrus canker and forced abandonment of eradication actions, the number of sprays increased to 3-4 for processed juice oranges and 10 for fresh market grapefruit. After the discovery of HLB in August 2005 and citrus black spot in 2010, the number of treatments rose to 8-9 sprays for processed juice fruit and 14 sprays for fresh market grapefruit aimed at both disease and ACP control combined with additional fertilizer treatments.

Costs per acre of foliar sprays for producing processed oranges in south-western Florida rose from USD 185.63 in 2003/2004 to USD 666.00 (+240\%) in 2014/2015 while fertilizer treatments went from USD 207.69 to USD $486.96(+134 \%)$ during the same timeframes. By comparison, costs per acre of foliar sprays for fresh market grapefruit in the Indian River area increased from USD 493.08 in 2003/2004 to USD $1300.40(+164 \%)$ in 2014/2015 while fertilizer treatments rose from USD 190.56 per acre in 2003/2004 to USD $452.55(+137 \%)$ per acre in 2014/2015. These totals do not include other cultural control costs nor cost for tree replacement. It was found that area-wide control of ACP through Citrus Health Management Areas provides an estimated differential gross economic benefit of USD 714 (USD 1218) for 2012/2013 (2013/2014) (Singerman and Page 2016).

Over the period from 2012/2013 to 2015/2016, HLB caused a cumulative loss of USD 1672 million in grower revenues (average of USD 418 million annually) resulting in average annual economic impacts to the Florida economy of -7945 jobs, -USD 658 million in value added, and USD 1098 million in industry output (Court et al. 2017). Citrus bearing acreage in Florida diminished from 576400 acres in 2005/2006 to 410700 (-29\%) in 2016/2017 while production value dropped from USD 1491136 in 2005/2006 to USD 1032227 (-30\%) in 2016/2017 (USDA-NASS 2006, 2017). 


\section{THE HLB IN MEXICO}

Mexico is the fourth largest producer of citrus in the world, with a total of 572000 ha in production, yielding 7.8 million tons annually (Table 1).

Table 1. Areas under citrus production for Mexican states - 2015 (SIAP 2017)

\begin{tabular}{|c|c|c|}
\hline State & Area (ha) & $\%$ \\
\hline Veracruz & 246750 & 43.13 \\
\hline Michoacán & 50276 & 8.79 \\
\hline Tamaulipas & 44432 & 7.77 \\
\hline San Luis Potosí & 37505 & 6.56 \\
\hline Puebla & 32067 & 5.61 \\
\hline Nuevo León & 31789 & 5.56 \\
\hline Oaxaca & 25469 & 4.45 \\
\hline Colima & 19748 & 3.45 \\
\hline Yucatán & 18189 & 3.18 \\
\hline Tabasco & 15532 & 2.72 \\
\hline Sonora & 8523 & 1.49 \\
\hline Guerrero & 7135 & 1.25 \\
\hline Jalisco & 6841 & 1.20 \\
\hline Hidalgo & 5680 & 0.99 \\
\hline Campeche & 4731 & 0.83 \\
\hline Chiapas & 4725 & 0.83 \\
\hline Quintana Roo & 3089 & 0.54 \\
\hline Baja California Sur & 2870 & 0.50 \\
\hline Sinaloa & 2729 & 0.48 \\
\hline Nayarit & 2469 & 0.43 \\
\hline Morelos & 610 & 0.11 \\
\hline Baja California & 383 & 0.07 \\
\hline Querétaro & 253 & 0.04 \\
\hline Zacatecas & 246 & 0.04 \\
\hline Total & 572051 & 100.00 \\
\hline
\end{tabular}

The major commercial citrus varieties grown in Mexico are orange (Citrus sinensis), Key lime (Citrus aurantifolia), Persian lime (Citrus latifolia), mandarin (Citrus reticulata) and grapefruit (Citrus paradisi) (Table 2). The value of this crop was estimate at USD 862 million (SIAP 2017).

HLB was first reported in samples of psyllids in July 2009 in Yucatán. In subsequent years more detections occurred in other states of the country (Table 3) (Trujillo-Arriaga 2014; SENASICA 2017a; SENASICA 2017b; SENASICA 2017c). In addition, infected psyllids were detected in Coahuila and Tamaulipas, where mechanisms of control and eradication of the disease vector have been implemented. 
Table 2. Production and value of principal citrus varieties in Mexico - 2015 (SIAP 2017)

\begin{tabular}{|l|c|c|}
\hline Citrus crop & $\begin{array}{c}\text { Production } \\
\text { (million tons) }\end{array}$ & $\begin{array}{c}\text { Value } \\
\text { (USD million) }\end{array}$ \\
\hline Limes (Key \& Persian) & 2.33 & 461 \\
\hline Orange & 4.52 & 345 \\
\hline Grapefruit & 0.42 & 33 \\
\hline Mandarin & 0.29 & 23 \\
\hline Total & $\mathbf{7 . 5 6}$ & $\mathbf{8 6 2}$ \\
\hline
\end{tabular}

Table 3. HLB detections in Mexico, after initial detection in the state of Yucatán in the month of July 2009 (Trujillo-Arriaga 2014; SENASICA 2017a; SENASICA 2017b; SENASICA 2017c)

\begin{tabular}{|l|l|l|l|}
\hline State & Detections of HLB & State & Detections of HLB \\
\hline Quintana Roo & August, 2009 & Tabasco & December, 2012 \\
\hline Jalisco & December, 2009 & Guerrero & March, 2013 \\
\hline Nayarit & December, 2009 & Puebla & September, 2013 \\
\hline Campeche & March, 2010 & Zacatecas & September, 2013 \\
\hline Colima & April, 2010 & Coahuila & December 2013* \\
\hline Veracruz & June, 2010 & Oaxaca & April, 2014 \\
\hline Sinaloa & July 2010* & Tamaulipas & June 2014* \\
\hline Michoacán & December, 2010 & Querétaro & October, 2015 \\
\hline Morelos & December 2010* & San Luis Potosí & October, 2015 \\
\hline Chiapas & March, 2011 & Nuevo León & December, 2015 \\
\hline Sonora & April 2011* & Veracruz & December, 2015 \\
\hline Hidalgo & April, 2011 & Tamaulipas & December, 2015 \\
\hline Baja California Sur & April, 2011 & Baja California & January, 2016 \\
\hline Nuevo León & August 2011* & Morelos & August, 2016 \\
\hline San Luis Potosí & September 2011* & Sonora & March, 2017 \\
\hline
\end{tabular}

*Infective psyllids

As of September 2017, HLB is recorded to infect plant material in all 24 citrusproducing states of Mexico (Fig. 1), where it has been detected in a total of 450 municipalities (SENASICA 2017a).

In Persian lime production in Yucatán, the presence of $\mathrm{Ca}$. L. asiaticus caused a reduction in weight of the fruit (17.3\%) and a decrease in the volume of juice $(18.6 \%)$ (Flores-Sánchez et al. 2015). In Key lime, experts estimated a reduction of 183168 tons should HLB become established throughout Mexico (Salcedo-Baca et al. 2010).

\section{RESPONSE TO HLB IN MEXICO}

The Mexican citrus industry, federal and state plant protection agencies responded to this situation with the following area-wide phytosanitary actions to manage the HLB disease: epidemiological surveillance in commercial orchards, urban areas, and sentinel gardens; and, chemical and biological controls of the insect vector in both backyards and commercial orchards in those regions where the weather conditions favour infection. 
Management of HLB is organized through Regional Control Areas (ARCOs), which implement the area-wide measures, and allow for coordination of monitoring, biological and chemical control actions across hundreds of ha; thereby preventing outbreaks from expanding to thousands of ha (SENASICA 2012).

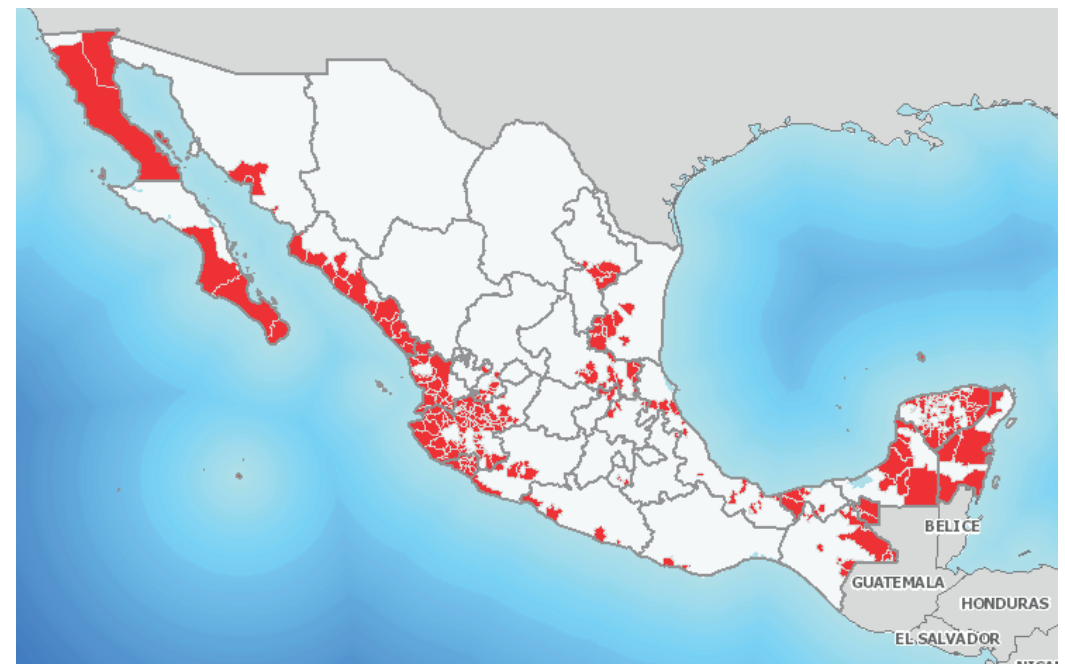

Figure 1. Areas in 24 states of Mexico with presence of HLB as of September 2017 (source SIRVEF 2019).

Since 2002, the vector of HLB has been present in Mexico, posing a significant risk for spreading HLB disease. Following the detection of HLB in Belize during 2008, the National Health, Food Safety and Food Quality Service (SENASICA in Spanish), of the General Directorate of Plant Health (DGSV in Spanish), initiated in 2008 a national priority campaign in 24 citrus states of the country. The aim of the programme was to detect the disease in a timely fashion and provide protection to more than 570000 ha of citrus. A series of protocols were developed and revised by DGSV with input from State Plant Health Committees and the affected industry (SENASICA 2008a, 2009).

In 2009, the programme received an allocation of USD 2.56 million that allowed for monitoring the disease in 77192 ha of commercial citrus and backyard trees (Sanchez 2013). As a result of these actions, the first detection of HLB found in infected ACP occurred in July 2009 in the town of Cuyo in the municipality of Tizimín, Yucatán (Trujillo-Arriaga 2011). In that same year and the following years, there were more detections in other states of the country (Table 3 ).

Due to the importance of the HLB to the Mexican citrus industry, efforts also were made at the federal and scientific levels to involve national universities and research centres to develop better management strategies, as well as better methods for the timely phytosanitary surveillance of the disease and the insect vector. To this end, SENASICA-DGSV established the legal bases for action as follows: 


\subsection{Phytosanitary Regulation}

With the detection in 2009 of HLB in Tizimín, Yucatán, the federal government issued as a matter of emergency, the Mexican Official Emergency Norm NOM-EM-047FITO-2009, which outlined and established phytosanitary actions to mitigate the risks of introduction and dispersal of HLB in Mexico (DOF 2009). It outlined the phytosanitary actions to implement a monitoring programme that included sampling, diagnosis, inspection and surveillance to assess any new introduction and further spread of HLB in the country and, where appropriate, the application of phytosanitary measures for its management. These included the delimitation of infected areas under phytosanitary control, the removal of infected material, the application of vector control methods, sampling, inspections, and restriction of the movement of vegetative material. The same actions are established in the "Protocol of Action to the Emergency by the Detection of $H L B "$ and are supported under the agreement that discloses the phytosanitary measures which should be applied for the control of HLB and its vector (DOF 2010). In addition, the DGSV and the State or Regional Technical Working Group issued the Protocol to establish the ARCOs (SENASICA 2012) for HLB and ACP.

\subsection{Sampling and Monitoring to Assess HLB Distribution}

With the presence of HLB in Mexico, one of the main activities carried out in all citrusproducing states of the country was an assessment of the presence of the disease through the collection of plant material and adult $D$. citri. Priority was given to the commercial areas of Key lime, Persian lime and orange. When symptomatic plant material was found, photographs were taken and sent through the Digital Diagnostic System (SIDIADI), so the trained technical staff, based on the visual symptoms, determined whether the material was suspect of HLB infection and further sampling was required. In commercial orchards, sampling of $D$. citri was done mainly in trees located along the periphery of the orchards, where 1 to 100 adults were collected and analysed by molecular techniques for presence of HLB. Urban areas (parks, tree-lined boulevards, harbours, etc.) were also sampled.

\subsection{Phytosanitary Diagnosis}

Given the need for timely diagnoses, four official laboratories were used where plant material and psyllids could be examined: 1) the National Phytosanitary Reference Center (CNRF) in Tecámac, Mexico state, 2) the National Quarantine Station of Epidemiology and Plant Sanitation in Querétaro; 3) State Committee of Plant Protection of Yucatán, and 4) State Committee of Plant Health of Colima. In addition, eight private laboratories were approved to assist with these diagnoses. Furthermore, the DGSV has a mobile phytosanitary diagnostic unit with adequate equipment required for HLB in situ detections such as bioclimatic chambers, real-time PCR and End-Point PCR. This excellent infrastructure reduced the response time to a minimum and allowed speedy decision-making to apply local or regional phytosanitary strategies as described in 3.4 through 3.6 below. 


\subsection{Cultural Control}

After an initial find of HLB positive vegetal material in a new area, the cultural control consisted of removing infected plants to avoid further spread from or possible resurgence of infection from new outbreaks. The following phytosanitary measures were implemented:

- All trees with symptoms of HLB should be eliminated within 5 days. For detections in commercial orchards, the owners were responsible for surveying all trees within their groves for the disease. Plants with symptoms were marked with a plastic tape indicating the branch(es) exhibiting symptoms. Plants located on the outer rows of orchards where the symptomatic plants were detected, were also marked with tape. Technical personnel checked each suspect orchard and confirmed whether or not the symptoms were caused by HLB. All positive cases were georeferenced. It was not considered necessary to sample these plants and technical personnel immediately removed the plants based upon a visual diagnosis. After tree removal, herbicides were applied to the stump. It is important to note that pruning cannot be used to manage HLB control and that replanting is not recommended as new plants are more susceptible to the disease (SENASICA 2010a; DOF 2010).

- In 2010 the Mexican government performed these activities in the following states with presence of HLB: Campeche, Colima, Jalisco, Michoacán, Nayarit, Quintana Roo, Sinaloa, and Yucatán. In these entities the exploration was carried out in 1553 localities, in which 1127275 citrus plants and 306138 plants of lakeview jasmine (Murraya paniculata (L.) Jack) were inspected in search of suspicious symptoms and psyllids carrying the bacteria. Likewise, 17539 citrus trees in orchards and 77522 of lakeview jasmine in backyards were eliminated, as well as 5037 trees of Mexican lemon, Persian lemon and orange, in commercial orchards and 1360626 nursery plants (SAGARPA 2011).

- The presence of HLB in all the plants was determined by searching for symptoms and sending samples to the laboratory for diagnosis by molecular techniques, including those in the proximity of citrus nurseries. All hosts present in nurseries without anti-aphid mesh protection were removed. When a detection occurred in a backyard, it was the responsibility of trained Auxiliary Plant Protection Organization staff to identify HLB symptoms (SENASICA 2010a; DOF 2010).

- In orchards where at least $28 \%$ of plants showed HLB symptoms and where the clinical diagnosis was positive for the disease, all trees in the orchard were removed within a period of no more than five calendar days. The review of orchards in an outbreak area is being implemented permanently, with a review of such orchards done every 3 weeks to know the status of the disease (SENASICA 2010a; DOF 2010).

Currently HLB control is still based on eradicating sick trees in the states with new detections. In areas with high incidence of HLB disease, the growers have opted to implement intensive nutrition programmes to extend the productive life of the affected plantations. The strategies of the federal government campaign are directed towards the control of the ACP, through the establishment of the ARCOs, which implement the biological and chemical control activities in their respective regional areas (SENASICA 2017d). 


\subsection{Biological Control of the Vector}

Augmentative biological control is a strategy that plays an important role in reducing the population density of $D$. citri, and its area-wide use in ARCOs has significantly contributed to reducing adverse environmental effects and minimizing interference with natural control of agricultural pests as a result of using agrochemicals (DGSV 2016).

In response to the detection of HLB and its vector $D$. citri in Mexico and to mitigate its threat for citriculture, SENASICA-DGSV and the CNRF established a Biological Control Programme for Asian Citrus Psyllid, as a complementary strategy to the integrated management of the HLB vector. The main activities in this programme have been:

- Search and selection of biological control agents of D. citri

- Mass-production of the species-specific ectoparasitoid Tamarixia radiata Waterston (Hymenoptera: Eulophidae)

- The release of adult parasitoids in specific areas not subject to insecticide application (such as urban areas, inaccessible areas, organic orchards, abandoned vegetable gardens, backyard host trees, orchards adjacent to urban areas, areas under integrated pest management, and protected natural areas or reserves)

- Assessment of the effectiveness of biological control agents in the laboratory and in the field

- Training and public education on the recognition and use of biological control agents of ACP

- Advice on the design of rearing facilities for T. radiata

- Optimization of the mass-production process of the parasitoid

- Research on different strains of T. radiata present in Mexico and their regional impact

- Research on the use of strains of entomopathogenic fungi, and finally

- Obtaining national and international support on parasitoid rearing (FAOSENASICA 2013).

Therefore, the DGSV through the CNRF, established collaborative agreements with the State Committees of Plant Protection in the states of Colima and Yucatán in 2009. The first agreement with the Entomophagous Insects Department of the National Reference Center for Biological Control (CNRCB), based in Tecomán, Colima, aims to generate technology (basic and applied) for the use of biological control agents of $D$. citri, as well as the production of T. radiata in Tecomán, Colima; while the second agreement with the Regional Mass-Rearing Laboratory of Tamarixia radiata in the Southeast has as its sole objective the mass-production of the parasitoid in Merida, Yucatán; both agreements are coordinated by the CNRCB (FAO-SENASICA 2013).

From 2010 to 2015, 31 million T. radiata were produced and released in citrus orchards and abandoned, urban and backyard areas of Yucatán, Quintana Roo, Campeche, Tabasco, Chiapas, Oaxaca, Hidalgo, and Guerrero. These release activities were supported by the State Plant Health Committees, who are responsible for transporting and release of parasitoids to the infested areas (CNRCB-CNRF-DGSV 2016). Many of these areas began with a parasitism rate ranging between $3-26 \%$ that increased to $70-85 \%$ after augmentative releases (SENASICA 2016). 
The recommended release rate is 100 parasitoids every 50-100 linear meters depending on the level of ACP infestation and density of host plants. If on average more than $20 \mathrm{D}$. citri nymphs were observed per tree shoot, 100 parasitoids were released every 50 meters (SENASICA 2015). The releases are carried out with a minimum interval of one month and a maximum of 3 months (DGSV 2016). These releases directly and indirectly benefit hundreds of growers.

With respect to the use of entomopathogenic fungi as a complement to the control of $D$. citri populations, the following research activities were established in support of the Biological Control Programme of the ACP:

- Exploration of entomopathogenic fungi

- Selection of isolates of entomopathogenic fungi candidates for the control of immature and adult stages of D. citri

- Evaluation of conidia production

- Evaluation of types of entomopathogenic fungi formulation

- Evaluation of fungal formulations in the field

- Evaluation of application equipment; and

- Biosafety tests (FAO-SENASICA 2013).

By 2016 three strains of Isaria javanica (formerly fumosorosea), CHE-CNRCB 303, 305 and 307, formerly Pf15, Pf17 and Pf21, respectively, as well as one of Metarhizium anisopliae (CHE-CNRCB 224, formerly Ma59), had been identified. Laboratory tests achieved $93-100 \%$ mortality in nymphs and up to $95 \%$ in adults of $D$. citri, respectively. Applications of entomopathogenic fungi in preliminary field trials reduced psyllid populations from 48 to 90\% (FAO-SENASICA 2013). In 2012 and 2013, the application of two strains of entomopathogenic fungi (Ma59 and Pf21) was carried out on 15932 ha in the states of Colima, Hidalgo, Jalisco, Nayarit, San Luis Potosí and Veracruz (CNRCB-CNRF-DGSV 2016).

\subsection{Chemical Control}

In other countries, HLB disease has been managed mainly through the suppression of vector populations using synthetic insecticides. In Mexico, only the use of insecticides authorized by COFEPRIS (DOF 2010) are recommended in accordance with the use of products that have been approved and shown to be efficacious in other countries. Cortéz-Mondaca et al. (2010) conducted tests of the effectiveness of conventional synthetic and organic insecticides with different modes of action, including botanical extracts, mineral oils, soaps, entomopathogenic detergents and growth regulators. Based on these results, the National Campaign against HLB has been rotating the use of the following active ingredients according to the specific local situations: thiamethoxam, imidacloprid + beta cyfluthrin, mineral oil, bifenthrin, tricarboxyls, chlorpyrifos, imidacloprid, dimethoate, thiamethoxam + lambda cyhalothrin, bifenthrin + zeta cypermethrin, azadirachtin, bifenthrin + abamectin, detergent and lime oxide (SENASICA 2012). 
In Mexico, chemical control is performed by the ARCOs. The application time is determined by the population dynamics of $D$. citri and the phenology of the citrus in each region. The spraying is done 2-3 times in all the orchards that are part of an ARCO within a two-week period of time. The State Plant Health Committees responsible for HLB disease management oversee the actions taken by ARCOs and inform growers about the timing of annual applications, and the overall pesticide management programme. ARCOs are responsible for any pesticide applications (DGSV 2016). In 2015 and 2016, 216566 and 273318 commercial ha of citrus were sprayed, respectively (SENASICA 2017b).

\subsection{Vegetative Material}

The Mexican Official Standard NOM-079-FITO-2002, "Phytosanitary Specifications for the Production and Mobilization of Propagation Material Free of Citrus Tristeza Virus and Other Pathogens Associated with Citrus", and the agreement that discloses the phytosanitary measures to be applied for the control of HLB and its vector (DOF 2002, 2010; SENASICA 2010a) establishes requirements for propagation and certification of citrus nursery stock through Certified Production Units as a means of providing disease-free trees for commercial sale and planting purposes.

\subsection{Training and Outreach}

Two international workshops on ACP and Citrus Huanglongbing were held in Mexico during 2008 and 2010, respectively, with the objective of providing training on disease diagnostics to technical staff in charge of field monitoring and sampling. Experts were invited from infected countries such as Belize, Brazil, China, Cuba and the USA, to share their experiences on management and disease prevention practices (SENASICA $2008 \mathrm{~b}, 2010 \mathrm{~b})$. In addition, three events on quarantine pests of citrus were organized in 2009, 2011, and 2013 (SENASICA 2013).

In order to create greater awareness among the general public about HLB and the risks posed, an additional 34667 training events were organized between 2008 and 2011 in different regions of the country. Attendees were encouraged to participate under the motto "All against HLB of citrus and its vector".

In addition, billboards along roadways and avenues in rural villages and information disseminated using printed triptychs, posters, flyers, technical files, postcards, radio spots and videos were used to educate all involved. These materials invited the public to be on the alert for symptoms of HLB in their commercial and backyard orchards, and to immediately report HLB symptoms to the local plant health boards in their region (Trujillo-Arriaga 2011). 


\section{HLB IMPACT ON CITRUS PRODUCTION FROM 2009 TO 2015}

In 2009, the year when HLB was first detected in Mexico, the area planted with lime, orange, mandarin and grapefruit comprised 523321 ha yielding a total of 6.82 million tons of fruit (SIAP 2017). That same year, SENASICA and the Inter-American Institute for Cooperation on Agriculture (IICA) commissioned a study to estimate the expected impact of HLB in Mexico (Salcedo-Baca et al. 2010).

Various scenarios were developed to assess potential impacts to the industry and economy with and without any governmental intervention. Under the low impact scenario, the study estimated that within five years following the establishment of the disease a loss of 2.7 million tons of citrus fruit would occur nationwide with an overall reduction of $39.6 \%$ in orange, $33 \%$ in grapefruit, $17 \%$ in mandarin, and $10 \%$ in lime production respectively. Under the high impact scenario, losses would increase to 3 million tons of fruit equivalent to $41 \%$ of orange, $53 \%$ of grapefruit, $26 \%$ of mandarin, and $18 \%$ of lime production.

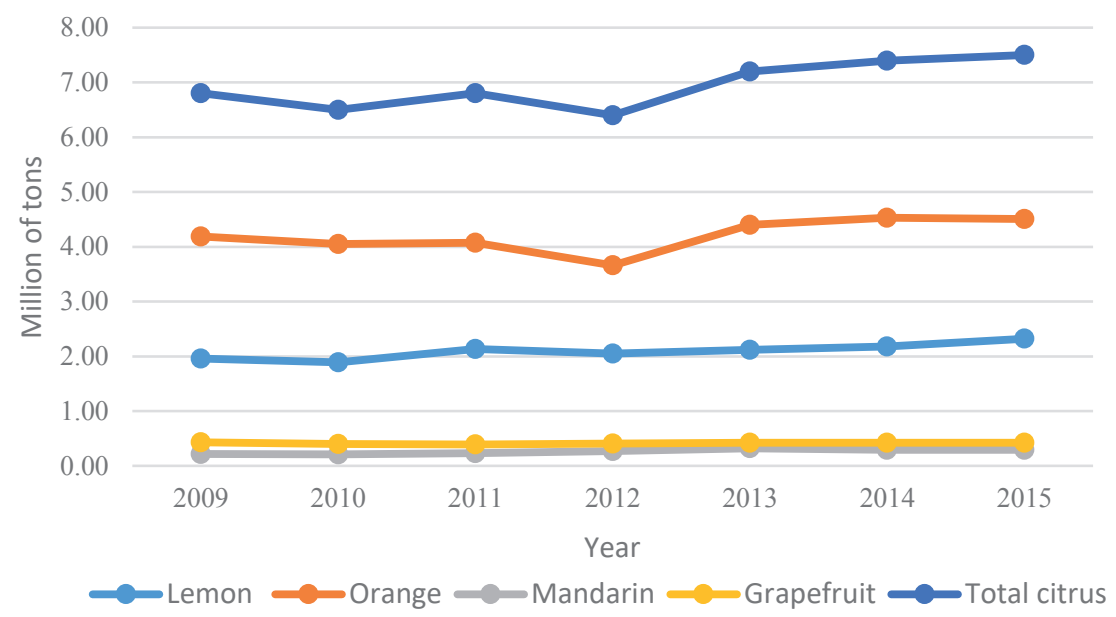

Figure 2. National citrus production in Mexico after HLB arrival in 2009 (SIAP 2017).

Six years after HLB was first detected in Mexico, however, with governmental intervention, the estimated losses in citrus production have yet to occur. Although citrus production in 2010 and 2012 decreased slightly, annual yields have remained fairly stable and have slightly increased by 0.7 million tons above the 2009 level (Fig. 2 and Table 4).

In 2016, the Mexican government allocated approximately USD 8.5 million to the HLB Programme. As a result of the successful application of the area-wide actions outlined above, Mexico largely mitigated the adverse effects of the disease, while at the same time slightly increasing citrus production. In addition, research programmes have been promoted among scientific institutions to generate propagative material tolerant or resistant to the disease. 
Table 4. State-by-state comparison of citrus production in Mexico - 2009 and 2015 (SIAP 2017)

\begin{tabular}{|c|c|c|c|c|c|c|c|c|}
\hline \multirow[t]{2}{*}{ State } & \multicolumn{5}{|c|}{ Production (tons) 2009} & \multicolumn{3}{|c|}{ Production (tons) 2015} \\
\hline & Orange & Lime & Mandarin & Grapefruit & Orange & Lime & Mandarin & Grapefruit \\
\hline Aguascalientes & 23 & 0 & 0 & 0 & 14 & 46 & 0 & 0 \\
\hline Baja California & 3,499 & 2,978 & 192 & 96 & 3,260 & 1,171 & 0 & 183 \\
\hline Baja California Sur & 29,303 & 144 & 0 & 66 & 49,995 & 309 & 22 & 495 \\
\hline Campeche & 37,018 & 5,953 & 215 & 15,014 & 25,122 & 10,325 & 332 & 18,955 \\
\hline Chiapas & 15,983 & 4,185 & 452 & 0 & 16,027 & 7416 & 404 & 0 \\
\hline Colima & 3,977 & 423,040 & 0 & 0 & 4,496 & 191890 & 0 & 158 \\
\hline Durango & 804 & 856 & 0 & 612 & 785 & 702 & 0 & 577 \\
\hline Guanajuato & 0 & 3 & 0 & 0 & 0 & 12 & 0 & 0 \\
\hline Guerrero & 4,189 & 78,404 & 230 & 66 & 4,435 & 71,867 & 138 & 9 \\
\hline Hidalgo & 45,481 & 2,589 & 262 & 0 & 59,041 & 2,231 & 239 & 0 \\
\hline Jalisco & 6,779 & 30,351 & 6 & 1,310 & 6,386 & 81,198 & 0 & 740 \\
\hline México & 327 & 1,227 & 0 & 0 & 234 & 1,190 & 39 & 0 \\
\hline Michoacán & 4,374 & 414,562 & 75 & 59,559 & 3,489 & 670,613 & 0 & 49,566 \\
\hline Morelos & 4,430 & 3,660 & 82 & 160 & 4,857 & 4,438 & 190 & 144 \\
\hline Nayarit & 1,576 & 14,093 & 41 & 5 & 712 & 18,423 & 19 & 0 \\
\hline Nuevo Leon & 296,973 & 0 & 35,892 & 17,734 & 313,439 & 0 & 45,751 & 26,201 \\
\hline Oaxaca & 60,626 & 176,182 & 0 & 5,440 & 56,290 & 245,137 & 0 & 1,161 \\
\hline Puebla & 254,841 & 48,352 & 680 & 11,160 & 214,175 & 28,211 & 51,746 & 5,067 \\
\hline Querétaro & 1,345 & 47 & 24 & 0 & 2,446 & 26 & 5 & 0 \\
\hline Quintana Roo & 32,289 & 1,107 & 32 & 0 & 16,841 & 26,222 & 112 & 0 \\
\hline San Luis Potosí & 431,567 & 8,599 & 20,358 & 55 & 337,717 & 21,986 & 22,212 & 62 \\
\hline Sinaloa & 16,970 & 2,173 & 1,420 & 5,195 & 19,320 & 1,648 & 446 & 2,887 \\
\hline Sonora & 167,371 & 988 & 581 & 17,500 & 142,445 & 1,564 & 3,059 & 16,689 \\
\hline Tabasco & 81,519 & 80,939 & 380 & 850 & 81,451 & 83,141 & 387 & 845 \\
\hline Tamaulipas & 539,526 & 46,411 & 54,235 & 29,083 & 668,935 & 121,200 & 11,618 & 46,544 \\
\hline Veracruz & $2,058,040$ & 514,728 & 102,046 & 256,064 & $2,336,427$ & 659,034 & 147,345 & 248,927 \\
\hline Yucatán & 94,534 & 104,777 & 6,441 & 11,704 & 147,107 & 74,463 & 6,885 & 5,106 \\
\hline Zacatecas & 128 & 0 & 72 & 0 & 74 & 1,605 & 130 & 0 \\
\hline Total & $4,193,484$ & $1,966,345$ & 223,718 & 431,671 & $4,515,520$ & $2,326,068$ & 291,078 & 424,315 \\
\hline
\end{tabular}


Although the government has successfully implemented area-wide strategies for regional control, it is necessary to further develop new and improved technologies. Mexico, Belize and USA have formed a Tri-National Working Group for purposes of technical exchange, information sharing, planning, coordination, and identification of research priorities.

Mexico currently has 573406 ha of citrus corresponding to 335019 ha of oranges, 180209 ha of limes (Key and Persian), 21297 ha of mandarin, 17590 ha of grapefruit, 12736 ha of tangerine, 5238 has of tangelo and 1317 ha of sweet limes, with an estimated annual production of 8 million tons per year, and whose production value is approximately USD 20424 million pesos (approximately USD 1.12 billion dollars) (SIAP 2017).

The first phytosanitary actions implemented on an area-wide basis were: timely detection of HLB in citrus and urban areas, elimination of infected plants in areas under control, suppression of the D. citri vector, and protection of propagative material within enclosed or screened nurseries.

\section{CONCLUSION}

In conclusion, as a result of the successful HLB Programme, citrus losses have been largely avoided in Mexico despite the fact that the disease has now been detected in all states of the country where commercial citrus is produced. Six years after the disease first appeared, the surface for the four principal citrus varieties actually increased by 5\%, from 523321 to 553671 ha (Fig. 3) (SIAP 2017).

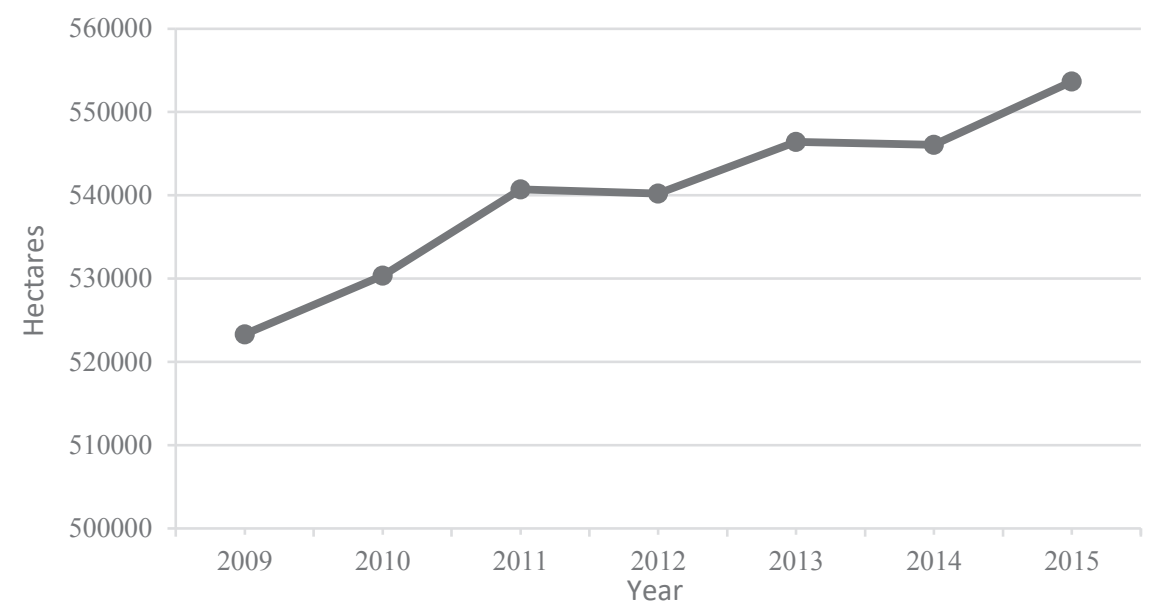

Figure 3. Expanding national areas of the four principal Citrus spp. produced in Mexico after the HLB arrival in 2009 (SIAP 2017). 


\section{REFERENCES}

Alemán, J., H. Baños, and J. Ravelo. 2007. Diaphorina citri y la enfermedad Huanglongbing: Una combinación destructiva para la producción citrícola. Revista de Protección Vegetal 22: 154-165.

Bové, J. M. 2006. Huanglongbing: A destructive, newly-emerging, century-old disease of citrus. Journal of Plant Pathology 88: 7-37.

Bové, J. M. 2012. Huanglongbing and the future of citrus in Sao Paulo state, Brazil. Journal of Plant Pathology 94: 465-467.

(CNRCB-CNRF-DGSV) Centro Nacional de Referencia de Control Biológico-Centro Nacional de Referencia Fitosanitaria-Dirección General de Sanidad Vegetal. 2016. El control biológico como parte de las campañas fitosanitarias y áreas regionales de control (ARCOs).

Collazo, M. L. C., R. Llauger, E. Blanco., I. Peña, D. López, C. González, J. C. Casín, L. Batista, E. Kitajima, F. A. O. Tanaka, R. B. Salaroli, D. C. Teixeira, E. C. Martins, and J. M. Bové. 2009. Occurrence of citrus huanglongbing in Cuba and association of the disease with Candidatus Liberibacter asiaticus. Journal of Plant Pathology 91: 709-712.

Cortéz-Mondaca, E., J. I. López-Arroyo, L. M. Hernández-Fuentes, A. Fú-Castillo, and J. LoeraGallardo. 2010. Control químico de Diaphorina citri Kuwayama en cítricos dulces en México: Selección de insecticidas y épocas de aplicación. Campo Experimental Valle del Fuerte, Los Mochis, Sinaloa. Folleto Técnico Núm. 35, INIFAP, Mexico. 22 pp.

Court, C. D., A. W. Hodges, M. Rahmani, and T. H. Spreen. 2017. Economic contributions of the Florida citrus industry in 2015-16. University of Florida. Institute for Food and Agricultural Sciences. Gainesville, Florida, USA. 35 pp.

da Graça, J. V., and L. Korsten. 2004. Citrus huanglongbing: Review, present status and future strategies. Diseases of Fruits and Vegetables 1: 229-245.

(DGSV) Dirección General de Sanidad Vegetal. 2016. Manual operativo de la campaña contra el Huanglongbing de los cítricos. Versión 1. México, D. F., México.

(DOF) Diario Oficial de la Federación. 2002. NORMA Oficial Mexicana NOM-079-FITO-2002. Requisitos fitosanitarios para la producción y movilización de material propagativo libre de virus tristeza y otros patógenos asociados a cítricos. México, D. F., México.

(DOF) Diario Oficial de la Federación. 2009. NORMA Oficial Mexicana de Emergencia NOM-EM-047FITO-2009, Por la que se establecen las acciones fitosanitarias para mitigar el riesgo de introducción y dispersión del Huanglongbing (HLB) de los cítricos (Candidatus Liberibacter spp.) en el territorio nacional. México, D. F., México.

(DOF) Diario Oficial de la Federación. 2010. ACUERDO por el que se dan a conocer las medidas fitosanitarias que deberán aplicarse para el control del Huanglongbing (Candidatus Liberibacter spp.) y su vector. México, D. F., México.

(FAO-SENASICA) Organización de las Naciones Unidas para la Alimentación y la Agricultura Servicio Nacional de Sanidad, Inocuidad y Calidad Agroalimentaria. 2013. Taller Subregional de Control Biológico de Diaphorina citri, Vector del HLB. Panamá, Panamá. 65 pp.

Flores-Sánchez, J. L., G. Mora-Aguilera, E. Loeza-Kuk, J. I. López-Arroyo, S. Domínguez-Monge, G. Acevedo-Sánchez, and P. Robles-García. 2015. Pérdidas en producción inducidas por Candidatus Liberibacter asiaticus en limón persa en Yucatán, México. Revista Mexicana de Fitopatología 33: 195 210.

Gottwald, T. R., C. I. Gonzales, and B. G. Mercado. 1991. Analysis of the distribution of citrus greening in groves in the Philippines, pp. 414-420. In R. H. Brlansky, R. F. Lee, and L. W. Timmer (eds.), Proceedings 11th Conference of the International Organization of Citrus Virologists (IOCV), Riverside, California, USA.

Gottwald, T. R., J. H. Graham, M. D. S. Irey, T. G. McCollum, and B. W. Wood. 2012. Inconsequential effect of nutritional treatments on huanglongbing control, fruit quality, bacterial titer and disease progress. Crop Protection 36: 73-82.

Halbert, S. E., and K. L. Manjunath. 2004. Asian citrus psyllids (Sternorrhyncha: Psyllidae) and greening disease of citrus: A literature review and assessment of risk in Florida. Florida Entomologist 87: 330 352.

Keremane, M. L., C. Ramadugu, A. Castaneda, J. E. Diaz, E. A. Peñaranda, J. Chen, Y. P. Duan, S. E. Halbert, and R. F. Lee. 2015. Report of Candidatus Liberibacter caribbeanus, a new citrus- and psyllid-associated Liberibacter from Colombia, South America. Oral Technical Session 101-O. 
Manjunath, K. L., S. E. Halbert, C. Ramadugu, S. Webb, and R. F. Lee. 2008. Detection of Candidatus Liberibacter asiaticus in Diaphorina citri and its importance in the management of citrus huanglongbing in Florida. Phytopathology 98: 387-396.

(NAPPO) North American Plant Protection Organization. 2005. New Federal Restrictions to Prevent Movement of Citrus Greening. Official Pest Reports. Ottawa, Canada.

Salcedo-Baca, D., R. A. Hinojosa, G. Mora-Aguilera, I. Covarrubias-Gutiérrez, F. J. R DePaolis, C. L Cíntora-González, and J. S. Mora-Flores. 2010. Evaluación del impacto económico de Huanglongbing (HLB) en la cadena citrícola Mexicana. Instituto Interamericano de Cooperación para la Agricultura (IICA). México, D. F., México. 141 pp.

Sanchez, H. M. 2013. Vigilancia estratégica para la detección de HLB. 3er Taller Internacional sobre Plagas Cuarentenarias de los Cítricos. Del 27 al 30 de agosto de 2013. Santiago, Manzanillo, México.

Schwarz, R. E., M. L. C. Knorr, and M. Prommintara. 1973. Presence of citrus greening and its psylla vector in Thailand. FAO Plant Protection Bulletin 21: 132-138.

(SAGARPA) Secretaría de Agricultura, Ganadería, Desarrollo Rural, Pesca y Alimentación. 2011. Boletín Informativo: Invierte SAGARPA más de 268 millones de pesos en la lucha contra el HLB. Delegación en el Estado de Guanjuato. Comunicación Social. 15 de febrero de 2011.

(SENASICA) Servicio Nacional de Sanidad, Inocuidad y Calidad Agroalimentaria. 2008a. Huanglongbing de los cítricos. Protocolos de actuación. México, D. F., México.

(SENASICA) Servicio Nacional de Sanidad, Inocuidad y Calidad Agroalimentaria. 2008b. $1^{\circ}$ Taller internacional sobre el Huanglongbing de los cítricos (Candidatus Liberibacter spp.) y el psílido asiático de los cítricos (Diaphorina citri). Del 7 al 9 de mayo del 2008. Hermosillo, Sonora. México.

(SENASICA) Servicio Nacional de Sanidad, Inocuidad y Calidad Agroalimentaria. 2009. "Protocolo de Actuación para la Detección de Huanglongbing”. México, D. F., México.

(SENASICA) Servicio Nacional de Sanidad, Inocuidad y Calidad Agroalimentaria. 2010a. Protocolo de actuación ante la emergencia por la detección del Huanglongbing. México, D. F., México.

(SENASICA) Servicio Nacional de Sanidad, Inocuidad y Calidad Agroalimentaria. 2010b. $2^{\circ}$ Taller Internacional sobre el Huanglongbing y el Psílido Asiático de los Cítricos. Del 19 al 23 de julio del 2010. Mérida, Yucatán, México.

(SENASICA) Servicio Nacional de Sanidad, Inocuidad y Calidad Agroalimentaria. 2012. Protocolo para establecer áreas regionales de control (ARCOs) del Huanglongbing y el psílido asiático de los cítricos. Dirección de Protección Fitosanitaria. México, D. F., México.

(SENASICA) Servicio Nacional de Sanidad, Inocuidad y Calidad Agroalimentaria. 2013. 3er Taller Internacional sobre Plagas Cuarentenarias de los Cítricos. Del 27 al 30 de agosto de 2013. Santiago, Manzanillo, México.

(SENASICA) Servicio Nacional de Sanidad, Inocuidad y Calidad Agroalimentaria. 2015. Manual de reproducción masiva de Tamarixia radiata. Principal parasitoide del psílido asiático de los cítricos, vector del HLB. Centro Nacional de Referencia de Control Biológico. México, D. F., México.

(SENASICA) Servicio Nacional de Sanidad, Inocuidad y Calidad Agroalimentaria. 2016. Laboratorio de Reproducción Masiva de Tamarixia radiata del Sureste. Mérida, Yucatán. 13 pp.

(SENASICA) Servicio Nacional de Sanidad, Inocuidad y Calidad Agroalimentaria. 2017a Huanglongbing de los cítricos. Informes y Evaluaciones 2017. México, D. F., México.

(SENASICA) Servicio Nacional de Sanidad, Inocuidad y Calidad Agroalimentaria. 2017b. Campañas y programas fitosanitarios - Huanglongbing de los cítricos. México, D. F., México.

(SENASICA) Servicio Nacional de Sanidad, Inocuidad y Calidad Agroalimentaria. 2017c. Huanglongbing de los cítricos. Informes y Evaluaciones 2016. México, D. F., México.

(SENASICA) Servicio Nacional de Sanidad, Inocuidad y Calidad Agroalimentaria. 2017d. Manual operativo de la campaña contra el Huanglongbing de los cítricos. Dirección de Protección FitosanitariaDGSV. México, D. F., México.39 pp.

(SIAP) Servicio de Información Agroalimentaria y Pesquera. 2017. Anuario Estadístico de la Producción Agrícola. México, D. F., México.

Singerman, A., and B. Page. 2016. What is the economic benefit of a Citrus Health Management Area (CHMA)? A case study. Document FE982. February 2016. University of Florida. Institute for Food and Agricultural Sciences. Gainesville, Florida, USA. 3 pp.

Singerman, A., and M. Burani-Arouca. 2017. Evolution of citrus disease management programs and their economic implications: The case of Florida's citrus industry. Document FE915. Revised January 2017. University of Florida. Institute for Food and Agricultural Sciences. Gainesville, Florida, USA. 5 pp.

(SIRVEF) Sistema Integral de Referencia para Vigilancia Epidemiológica Fitosanitaria. 2019. Dirección General de Sanidad Vegetal, México. 
Trujillo-Arriaga, F. J. 2011. HLB en México. Situación actual, regulación y perspectivas de áreas regionales para el manejo del HLB. 3er Encuentro Internacional de Investigación en Cítricos. Septiembre de 2011. Martínez de la Torre, Veracruz, México.

Trujillo-Arriaga, F. J. 2014. Reporte de México. 38 Reunión Anual de la NAPPO. Del 20 al 24 de octubre. Huatulco, Oaxaca, México. En línea

(USDA-NASS) United States Department of Agriculture-National Agricultural Statistical Service. 2006. Citrus Fruits 2006 Summary. Washington, DC, USA. 49 pp.

(USDA-NASS) United States Department of Agriculture-National Agricultural Statistical Service. 2017. Citrus Fruits 2017 Summary. Washington, DC, USA. 34 pp.

Vojnov, A. A., A. M. do Amaral, J. M. Dow, A. P. Castagnaro, and M. R. Marano. 2010. Bacteria causing important diseases of citrus utilize distinct modes of pathogenesis to attack a common host. Applied Microbiology and Biotechnology 87: 467-477.

Wang, N., L., Wenbin, M. Irey, G. Aibrigo, K. Bo, and J. Kim. 2009. Citrus huanglongbing. Tree and Forestry Science and Biotechnology 3(Special Issue 2): 66-72. 